\title{
Efektivitas Pelatihan Kebermaknaan Kerja untuk Meningkatkan Keterikatan Karyawan pada Perawat
}

\author{
Rifa Juniartika $^{(1)}$, Erita Yuliasesti Diah Sari ${ }^{(2)}$, Herlina Siwi Widiana ${ }^{(3)}$ \\ ${ }^{(1)}$ Magister Profesi Psikologi, Universitas Ahmad Dahlan, Yogyakarta, Indonesia \\ ${ }^{(2),(3)}$ Fakultas Psikologi Universitas Ahmad Dahlan Yogyakarta, Indonesia \\ One of the important human resources in hospital is nurses. Nurses with high employee \\ engagement are expected to be able to provide excellent services to patients so that they can \\ increase public trust in hospitals as health care. When demonstrating low sense of engagement \\ with their job in a hospital, nurses tend to be less friendly towards patients, causing complaints \\ from patients. One effort to increase employee engagement is by providing work \\ meaningfulness training. To this end, the purpose of this study was to examine the effectiveness \\ of work meaningfulness training to improve employee engagement among nurses in hospitals. \\ Participants were 16 nurses who were randomly assigned to either an experimental group or \\ control group. The research design in this study was pretest-posttest control group design. The \\ result showed a significant effect of work meaningfulness training on the level of employee \\ engagement.
}

Keywords: employee engagement, work meaningfulness, work meaningfulness training

Perawat adalah salah satu sumber daya penting dalam rumah sakit. Perawat dengan keterikatan karyawan yang tinggi diharapkan mampu memberikan pelayanan yang prima terhadap pasien sehingga dapat meningkatkan kepercayaan masyarakat terhadap rumah sakit sebagai penyedia jasa layanan kesehatan. Keterikatan karyawan yang rendah pada perawat di rumah sakit menimbulkan perilaku kurang ramah perawat kepada pasien sehingga menyebabkan komplain dari pasien. Salah satu upaya untuk meningkatkan keterikatan karyawan tersebut ialah memberikan pelatihan kebermaknaan kerja. Tujuan penelitian ini ialah untuk menguji efektivitas pelatihan kebermaknaan kerja dalam meningkatkan keterikatan karyawan pada perawat di rumah sakit. Subjek dalam penelitian adalah 16 orang perawat di sebuah rumah sakit yang secara random terbagi menjadi kelompok eksperimen dan kelompok kontrol. Desain penelitian adalah pretest-posttest control group design. Hasil penelitian menunjukkan adanya pengaruh signifikan pelatihan kebermaknaan kerja terhadap tingkat keterikatan karyawan.

Kata kunci: kebermaknaan kerja, keterikatan karyawan, pelatihan kebermaknaan kerja

MEDIAPSI, 2020, Vol. 6(1), 26-36, DOI: https://doi.org/10.21776/ub.mps.2020.006.01.4

Received: 26-06-2019. Revised: 18-08-2019. Accepted: 07-04-2020. Published online: 12-06-2020

Handling Editor: Intan Rahmawati, Universitas Brawijaya, Malang, Indonesia

*Corresponding author: Rifa Juniartika, Magister Profesi Psikologi, Universitas Ahmad Dahlan, Yogyakarta, Indonesia. E-mail: rifajuniartika@gmail.com

This work is licensed under a Creative Commons Attribution-NonCommercial 4.0 International License.

How to cite this article in accordance with the American Psychological Association (APA) $6^{\text {th }}$ guidelines:

Juniartika, R., Sari, E. Y. D., \& Widiana, H. S. (2020). Efektivitas pelatihan kebermaknaan kerja untuk meningkatkan keterikatan karyawan pada perawat. MEDIAPSI, 6(1), 26-36. https://doi.org/10.21776/ub.mps.2020.006.01.4

\section{Pendahuluan}

Rumah sakit merupakan salah satu industri jasa pelayanan kesehatan sebagai bagian penting dari sistem kesehatan. Rumah sakit menyediakan pelayanan kuratif, pelayanan gawat darurat, pusat alih pengetahuan dan 
teknologi serta berfungsi sebagai pusat rujukan. Hal ini sejalan dengan keputusan Menteri Kesehatan Republik Indonesia No. 340/MENKES/PER/III/2010 Pasal 1 ("Kebijakan kesehatan Indonesia", 2010) yang menyatakan bahwa rumah sakit adalah institusi pelayanan kesehatan yang menyelenggarakan pelayanan kesehatan perorangan secara paripurna dan menyediakan pelayanan rawat inap, rawat jalan, serta gawat darurat. Berdasarkan uraian di atas, dapat disimpulkan bahwa produk umum industri rumah sakit adalah jasa pelayanan kesehatan.

Penyelenggaraan pelayanan kesehatan yang bermutu terhadap masyarakat membutuhkan kinerja prima dari petugas yang terlibat dalam pelayanan kesehatan tersebut. Oleh karena itu, SDM (Sumber Daya Manusia) yang bekerja di rumah sakit memiliki peran penting dalam memberikan pelayanan tersebut. Namun faktanya, beberapa rumah sakit di Indonesia belum memiliki SDM yang mampu menjalankan tugasnya secara optimal. Hal ini mengakibatkan munculnya ketidakpuasan dari pasien terhadap pelayanan di rumah sakit.

Berdasarkan konsep JD-R (Job Demands Resource) model menurut Bakker dan Leiter (2010), kinerja karyawan yang kurang optimal disebabkan karyawan kurang merasakan keterikatan atau engagement dengan pekerjaannya. Karyawan yang memiliki keterikatan pada pekerjaannya akan menunjukkan produktivitas atau kinerja yang baik, yang terlihat dari kinerja yang ditunjukkan oleh perawat di suatu rumah sakit. Oleh karena itu, keterikatan karyawan yang tinggi sangat dibutuhkan untuk dapat meningkatkan produktivitas rumah sakit sebagai penyelenggara pelayanan kesehatan.

Keterikatan kerja menurut Schaufeli (2013) adalah kondisi positif dan pemenuhan karyawan yang berhubungan dengan pekerjaan. Karyawan yang memiliki keterikatan dengan perusahaan akan berkomitmen secara emosional dan intelektual terhadap perusahaan serta akan memberikan usaha terbaiknya melebihi target yang telah ditentukan dalam suatu pekerjaan (Nusantria, 2012). Schaufeli (2013) menjelaskan tiga aspek pembentuk keterikatan karyawan yaitu vigor, dedication dan absorption.

Vigor menunjukkan adanya kesediaan karyawan untuk melakukan usaha yang besar dalam menyelesaikan pekerjaan, tidak mudah merasa lelah, dan tekun dalam melakukan pekerjaan. Dedication menggambarkan perasaan antusias karyawan dalam bekerja, bangga dengan pekerjaan yang dilakukan, serta merasa terinspirasi dan tertantang dengan pekerjaan. Absorption menggambarkan keadaan karyawan terbenam secara total, merasa senang melakukan pekerjaannya dan merasa sulit untuk melepaskan diri dengan pekerjaan. Karyawan yang memiliki ketiga aspek ini dalam dirinya merupakan karyawan yang memiliki keterikatan yang tinggi terhadap pekerjaannya sehingga akan memberikan kontribusi terbaik untuk memajukan perusahaan yang menaunginya.

Berdasarkan pengambilan data awal yang dilakukan oleh peneliti melalui observasi di Rumah Sakit X Padang, diketahui bahwa terdapat karyawan yang tidak menunjukkan usaha lebih dalam melakukan tugasnya sebagai perawat. Hal ini ditunjukkan dengan sikap petugas pada bagian laboratorium yang tidak menjawab pertanyaan pasien dengan ramah. Pada saat pengamatan dilakukan, karyawan tersebut tampak menjawab pertanyaan pasien tanpa memandang ke wajah pasien yang bertanya. Selain itu, karyawan tersebut tidak berusaha memberikan jawaban yang dibutuhkan oleh pasien dengan baik. Pada pertanyaan keempat, karyawan tersebut justru menjawab dengan ketus pertanyaan pasien dan menyarankan pasien tersebut untuk bertanya ke pihak lain di laboratorium sembari melanjutkan kegiatan menulis.

Sikap yang ditunjukkan oleh karyawan tersebut menunjukkan tidak adanya usaha yang besar untuk menjawab pertanyaan pasien dengan baik. Hal itu menimbulkan 
ketidakpuasan pada pasien yang ditunjukkan dengan meninggalkan meja pelayanan tanpa mengucapkan terima kasih atas jawaban yang sebelumnya diberikan oleh petugas. Selanjutnya, pasien kembali melewati petugas tersebut dengan mengucapkan kata-kata yang mengungkapkan kekecewaannya terhadap pelayanan yang diberikan. Ketidakramahan yang ditunjukkan oleh karyawan tersebut merupakan permasalahan keterikatan karyawan pada aspek vigor.

Fakta lain diperoleh berdasarkan wawancara awal terhadap karyawan divisi marketing yang bertanggung jawab menerima komplain dari pasien BPJS. Karyawan tersebut mengatakan bahwa terdapat pasien yang mengeluhkan ketidakpuasan terhadap sikap seorang perawat. Hal itu terjadi ketika pasien bertanya mengenai hal yang harus dilakukan oleh pasien setelah mendapatkan penanganan serta aturan dalam meminum obat, perawat memberikan jawaban dengan tidak ramah. Sikap perawat tersebut menimbulkan ketidakpuasan dari pasien sehingga menyampaikan komplain kepada pihak rumah sakit.

Karyawan divisi marketing yang bertugas merangkum kronologi dan keluhan yang disampaikan oleh pasien tersebut mengatakan bahwa kejadian tersebut tidak hanya terjadi satu atau dua kali, namun lebih dari dua kali. Selain itu, karyawan juga melakukan peninjauan terhadap perawat. Berdasarkan penjelasan karyawan divisi marketing tersebut, perawat mengaku sudah menyampaikan informasi dengan sangat jelas namun pasien tidak mengerti apa yang disampaikan oleh perawat. Sementara itu, perawat memiliki tugas lain dari dokter yang juga mendesak sehingga meninggalkan pasien begitu saja dengan perasaan kesal.

Sikap perawat pada kejadian tersebut merupakan perilaku yang tidak menunjukkan rasa bangga terhadap pekerjaan yang dilakukan. Perawat tidak menunjukkan perasaan antusias dalam memberikan pelayanan yang ramah terhadap pasien. Kejadian tersebut menunjukkan bahwa perawat tidak merasa tertantang untuk menghadapi pasien yang mengalami kesulitan dalam memahami informasi yang disampaikan, yang menyebabkan perawat tidak berusaha mengubah cara berkomunikasi terhadap pasien agar pasien dapat mengerti. Kondisi tersebut merupakan permasalahan keterikatan karyawan pada aspek dedication.

Selanjutnya, berdasarkan pengambilan wawancara awal yang dilakukan terhadap karyawan bagian SDM diperoleh informasi bahwa perawat di Rumah Sakit X Padang sering bekerja lembur dengan alasan adanya tindakan terhadap pasien atau menggantikan perawat lain yang berhalangan hadir. Karyawan tersebut juga menjelaskan bahwa sebelum pulang kerja, perawat menyelesaikan pekerjaan terlebih dahulu atau berbincang-bincang dengan rekan kerja hingga jam kerja berakhir.

Perilaku perawat seperti yang diungkapkan oleh karyawan SDM tersebut menunjukkan bahwa perawat di Rumah Sakit X Padang bersedia bekerja lembur dan menyelesaikan pekerjaannya sebelum meninggalkan tempat kerja. Meskipun demikian, bekerja lembur tersebut dilakukan bukan karena keinginan perawat melainkan situasi yang menjadikan perawat tersebut harus bekerja lembur, yaitu ketika ada tindakan terhadap pasien atau menggantikan rekan kerja yang tidak hadir. Selain itu, perilaku karyawan yang cenderung berbincang-bincang dengan rekan kerja sebelum jam kerja berakhir tidak menunjukkan perilaku karyawan yang larut dalam pekerjaannya. Perilaku karyawan tersebut belum menunjukkan seorang karyawan yang merasakan sulit melepaskan diri dari pekerjaan. Kondisi ini menunjukkan permasalahan keterikatan karyawan pada aspek absorption.

Uraian mengenai bentuk perilaku yang ditunjukkan oleh perawat di Rumah Sakit X Padang tersebut mengindikasikan bahwa tingkat keterikatan karyawan masih berada pada 
kategori not engaged. Menurut hasil survei yang dilakukan oleh Gallup (2017), karyawan yang berada pada kategori not engaged cenderung fokus terhadap tugas dibandingkan pencapaian tujuan pekerjaan tersebut. Karyawan pada kategori ini hanya mengerjakan pekerjaan sesuai porsi mereka dan sesuai yang dibayarkan organisasi, dalam bekerja selalu menunggu perintah dari atasan dan cenderung merasa tidak memiliki energi ketika bekerja. Sementara itu, Nusantria (2012) mengatakan bahwa karyawan dengan keterikatan yang tinggi akan berkomitmen secara emosional dan intelektual terhadap perusahaan serta akan memberikan usaha terbaiknya melebihi apa yang dijadikan target dalam suatu pekerjaan. Hal ini menunjukkan bahwa keterikatan karyawan di Rumah Sakit X Padang masih perlu ditingkatkan.

Dampak dari rendahnya keterikatan karyawan pada perawat di Rumah Sakit X Padang antara lain kurangnya kepercayaan masyarakat terhadap kualitas pelayanan Rumah Sakit X Padang sehingga juga akan mempengaruhi profit rumah sakit. Selain itu, perawat dengan keterikatan karyawan yang tinggi diharapkan memiliki kesadaran untuk terus meningkatkan kualitas kerja serta bersedia memberikan kontribusi lebih dari yang diharapkan oleh rumah sakit dalam pekerjaannya. Apabila hal ini terjadi maka karyawan turut berperan dalam memajukan kualitas pelayanan kesehatan yang disediakan oleh rumah sakit sehingga mampu meningkatkan kepuasan pasien terhadap rumah sakit.

Bakker dan Demerouti (2008) menyatakan bahwa faktor yang mempengaruhi keterikatan karyawan diantaranya faktor eksternal yaitu tuntutan kerja (job demands), sumber kerja (job resources) dan salience of job resources. Selain itu, faktor internal juga berpengaruh, yang mencakup sumber pribadi (personal resources) yang meliputi modal psikologis, kepribadian, sifat, usia dan lain-lain. Kahn (1990) menyatakan bahwa kebermaknaan (meaningfulness) menjadi salah satu kondisi psikologis yang mempengaruhi seseorang ketika mengalami keterikatan, selain kondisi psikologis lain yaitu ketersediaan (availability) dan keamanan (safety). Rendahnya modal psikologis akan menimbulkan stressor atau tekanan pada karyawan dan rendahnya tingkat motivasi sehingga akan mempengaruhi keterikatan kerja karyawan (Bakker \& Demerouti, 2007).

Berdasarkan fakta yang ditemukan di Rumah Sakit X Padang, faktor yang mempengaruhi keterikatan karyawan terdiri dari faktor eksternal dan faktor internal. Faktor eksternal yang mempengaruhi yaitu tuntutan kerja. Hal ini telah dijelaskan oleh karyawan pihak marketing yang menyampaikan keluhan para perawat terkait dengan tuntutan kerja dari dokter. Selanjutnya, faktor internal yang mempengaruhi keterikatan karyawan ialah kondisi psikologis karyawan yang mengalami stress atau tekanan dari berbagai sumber dalam pekerjaannya. Faktor-faktor tersebut menjadi pemicu munculnya sikap yang menunjukkan rendahnya keterikatan karyawan yang dimiliki oleh perawat.

Berdasarkan penelitian yang dilakukan oleh May, Gilson, dan Harter (2004), ditemukan bahwa kebermaknaan kerja menunjukkan hubungan positif yang paling signifikan dengan keterikatan karyawan. Hal ini didukung oleh penelitian yang dilakukan oleh Fairlie (2011) yang menyebutkan bahwa kebermaknaan kerja memiliki hubungan dengan keterikatan karyawan dalam mempengaruhi karakteristik pekerjaan.

Kebermaknaan kerja merupakan kecenderungan seseorang untuk memaknai pekerjaannya sebagai pekerjaan (job), sebagai karir (career), dan sebagai panggilan (calling) (Wrzesniewski, McCauley, Rozin, \& Schwartz,1997). Dinamika yang terjadi pada karyawan dengan kebermaknaan kerja adalah bahwa karyawan akan mempersepsi atau menilai pekerjaannya sebagai sebuah panggilan, ciri khas pribadi, dan individu memiliki 
keterhubungan dengan sesuatu yang lebih besar dan menjadi pekerja di dalam pekerjaan itu sendiri (Fairlie 2011). Karyawan yang telah mempersepsikan dan menilai pekerjaan sebagai sebuah aktivitas yang bermakna akan bekerja dengan sungguh-sungguh dengan kualitas pekerjaan yang terbaik. Fakta yang terjadi pada perilaku kerja karyawan di Rumah Sakit X Padang kurang mengindikasikan bahwa karyawan memaknai pekerjaannya sehingga karyawan tidak menunjukkan kualitas kerja terbaik mereka. Hal ini menunjukkan bahwa karyawan pada Rumah Sakit X Padang membutuhkan pemahaman mengenai kebermaknaan kerja untuk dapat meningkatkan keterikatan karyawan yang ditunjukkan dengan kualitas kerja.

Penelitian mengenai efektivitas pelatihan kebermaknaan kerja untuk meningkatkan keterikatan karyawan sudah pernah dilakukan sebelumnya terhadap PNS di Pemerintah Kota Surakarta (Hidayat, 2018). Partisipan pada penelitian tersebut yaitu staf PNS di Pemerintah Kota Surakarta yang berjumlah 44 orang. Metode pengumpulan data yang digunakan ialah skala keterikatan pegawai, observasi dan wawancara. Penelitian sejenis juga pernah dilakukan oleh Firdaus (2017) yang menunjukkan bahwa makna kerja berpengaruh positif dan signifikan terhadap work engagement.

Perbedaan penelitian yang dilakukan oleh peneliti dengan penelitian terdahulu terletak pada subjek penelitian, waktu pelaksanaan penelitian, tempat pelaksanaan penelitian, metode penelitian, skala yang digunakan, metode analisis data yang digunakan, serta budaya yang mempengaruhi respon dari subjek penelitian. Subjek penelitian merupakan karyawan Rumah Sakit X Padang yang berprofesi sebagai perawat. Penelitian dilakukan dengan mengadakan pelatihan Kebermaknaan Kerja terhadap subjek penelitian.

Berdasarkan latar belakang masalah di atas, maka tujuan dari penelitian ini adalah untuk mengetahui pengaruh pelatihan kebermaknaan kerja terhadap keterikatan karyawan pada Rumah Sakit X Padang. Hipotesis yang diajukan dalam penelitian ini adalah ada perbedaan tingkat keterikatan karyawan pada kelompok eksperimen antara sebelum dan sesudah mengikuti pelatihan kebermaknaan kerja. Setelah mengikuti pelatihan kebermaknaan kerja maka tingkat keterikatan karyawan akan lebih tinggi dibandingkan sebelum mengikuti pelatihan.

\section{Metode}

\section{Partisipan dan desain penelitian}

Penelitian ini diawali dengan memberikan skala keterikatan karyawan kepada seluruh perawat di Rumah Sakit X Padang sebagai tahapan pre-test. Tahap ini memperoleh sebanyak 63 orang perawat yang mengisi skala keterikatan karyawa. Setelah dianalisis, diketahui bahwa sebanyak 33 orang berada pada kategori keterikatan karyawan sedang, sebanyak 30 orang pada keterikatan karyawan tinggi. Oleh karena itu, sebanyak 32 orang yang berada pada kategori sedang diambil sebagai subjek penelitian.

Selanjutnya, subjek penelitian yang berjumlah 32 orang dibagi menjadi dua kelompok yaitu sebanyak 16 orang pada kelompok eksperimen dan 16 orang pada kelompok kontrol. Pembagian dilakukan berdasarkan kehadiran karyawan pada hari pertama dilaksanakan pelatihan kebermaknaan kerja. Pelatihan kebermaknaan kerja dilakukan satu minggu setelah pre-test diberikan. Pelatihan kebermaknaan kerja tersebut dilakukan sebanyak empat kali pertemuan.

Selama pelatihan kebermaknaan kerja berlangsung, jumlah subjek yang hadir pada setiap pertemuan semakin berkurang. Hal ini terjadi karena jadwal pekerjaan dan beberapa alasan pribadi dari masing-masing subjek yang berhalangan untuk hadir, sehingga hanya terdapat tiga orang yang hadir secara konsisten sebanyak empat kali pertemuan berturut-turut. Setelah pelatihan kebermaknaan kerja selesai 
dilaksanakan, peneliti kembali memberikan skala keterikatan karyawan sebagai post-test dua minggu setelah pelatihan kebermaknaan kerja berakhir. Skala keterikatan karyawan kembali diberikan sebagai follow up dua minggu setelah skala post-test diberikan. Skala keterikatan karyawan pada saat post-test dan follow up diberikan pada kelompok eksperimen maupun kelompok kontrol untuk melihat perbandingan skor yang diperoleh.

Penelitian ini menggunakan metode penelitian eksperimental. Penelitian ekperimen adalah penelitian yang digunakan untuk mencari pengaruh perlakuan tertentu terhadap variabel lain dalam kondisi yang terkendalikan. Kondisi yang terkendalikan adalah adanya hasil dari penelitian yang dikonversikan ke dalam angka-angka, untuk selanjutnya dianalisis meggunakan statistik uji perbedaan (Sugiyono 2014).

Desain penelitian yang digunakan yaitu pretest - posttest control group design. Desain ini dianggap baik karena sudah memenuhi persyaratan yang berkaitan dengan adanya kelompok kontrol tidak dikenai eksperimen tetapi tetap mendapatkan pengamatan (Arikunto 2013). Berdasarkan desain ini, kelompok eksperimen maupun kelompok kontrol memiliki karakteristik yang sama karena diambil secara acak (random) dari populasi yang homogen (Sugiyono 2014).

Kriteria subjek penelitian yang digunakan dalam penelitian ini adalah karyawan Rumah Sakit X Padang yang berprofesi sebagai perawat dan memiliki tingkat keterikatan karyawan pada kategori sedang atau rendah berdasarkan hasil pengisian skala keterikatan karyawan. Keterikatan karyawan (employee engagement) diukur dengan menggunakan skala keterikatan karyawan yang disusun dan dikembangkan oleh Titien (2016). Skala keterikatan karyawan tersebut dirancang dengan berlandaskan pada konsep teoretis dari Schaufeli dan Bakker (2004). Dimensi konstrak yang digunakan dalam penelitian ini adalah vigor, dedication, dan absorption (Schaufeli \&
Bakker, 2004). Total aitem yang digunakan berjumlah 32 dengan 5 rentang respon dari Sangat Tidak Sesuai (skor $=1$ ) sampai dengan Sangat Sesuai $($ skor $=5)$.

\section{Prosedur dan pengukuran}

Uji reliabilitas terhadap aitem-aitem pada skala Keterikatan Karyawan dilakukan menggunakan Alpha Cronbach, yang menghasilkan koefisien reliabilitas sebesar $\alpha=$ 0.934. Nilai tersebut diperoleh setelah aitemaitem yang memiliki nilai di bawah 0.4 dikeluarkan. Sementara itu, hasil uji validitas isi dilandaskan pada evaluasi 32 aitem oleh 15 orang yang ahli di bidang psikologi. Hasil uji validitas isi berkisar antara 0.645 sampai dengan 0.98 (Titien 2016).

Skala keterikatan karyawan diberikan pertama kali satu minggu sebelum perlakuan diberikan. Proses ini dilakukan sebagai tahapan pre-test untuk memperoleh gambaran awal keterikatan karyawan pada perawat di Rumah Sakit X Padang. Selain itu, tahap ini juga digunakan sebagai tahap screening untuk mendapatkan subjek penelitian yang sesuai dengan kriteria yang telah ditetapkan. Selanjutnya, subjek penelitian yang didapatkan dibagi ke dalam dua kelompok yaitu kelompok eskperimen dan kelompok kontrol. Pembagian subjek ke dalam masing-masing kelompok dilakukan secara acak berdasarkan kehadiran subjek pada hari pertama pelatihan. Subjek yang hadir pada hari pertama pelatihan dimasukkan ke dalam kelompok eksperimen sementara subjek yang tidak hadir dimasukkan ke dalam kelompok kontrol.

Perlakuan yang diberikan kepada kelompok eksperimen berupa pelatihan kebermaknaan kerja. Pelatihan kebermaknaan kerja dalam penelitian ini menggunakan konsep kebermaknaan kerja yang mengacu pada teori Steger dan Dik (2009) untuk mendorong perilaku keterikatan karyawan. Kebermaknaan kerja menurut Steger dan Dik (2009) memiliki tiga aspek yaitu positive meaning in work, meaning-making through work, dan greater 
good motivation. Metode yang digunakan dalam pelatihan ini yaitu experiential learning yaitu proses belajar yang terjadi ketika partisipan sedang melakukan suatu aktivitas kemudian ia memperhatikan dan menganalisis aktivitas yang dilakukan itu secara kritis lalu mencari insight (pemahaman) yang berguna dari analisis tadi dan menerapkan insight tersebut dalam perilaku yang akan datang (Rae 2005). Panduan yang digunakan dalam pelaksanaan pelatihan disusun oleh peneliti dengan diuji menggunakan professional judgement sebelum digunakan.

Dua minggu setelah kelompok eksperimen mendapatkan perlakuan berupa pelatihan kebermaknaan kerja, seluruh subjek penelitian baik kelompok eksperimen maupun kelompok kontrol kembali disajikan skala keterikatan karyawan sebagai post-test. Pemberian post-test dilakukan untuk mengetahui perbedaan tingkat keterikatan karyawan yang terjadi pada kelompok eksperimen sebelum dan setelah perlakuan diberikan. Sementara itu, kelompok kontrol berfungsi sebagai pembanding jika terdapat perbedaan skor pre-test dan skor post-test pada kelompok eksperimen. Selanjutnya, dua minggu setelah pemberian post-test subjek penelitian kembali diberikan skala keterikatan karyawan sebagai tahap follow up. Tahap ini dilakukan untuk mengetahui ketahanan efektivitas pelatihan kebermaknaan kerja pada kelompok eksperimen.

Setelah peneliti memperoleh seluruh data pre-test, post-test dan follow up, maka data tersebut dianalisis menggunakan beberapa teknik analisis dengan bantuan aplikasi SPSS. Tahapan analisis data diawali dengan melakukan uji homogenitas menggunakan teknik homogeneity of variances menggunakan aplikasi SPSS. Selanjutnya, uji hipotesis dilakukan menggunakan Friedman test dan Mann-Whitney U test.

\section{Hasil}

Deskripsi penelitian yang diperoleh dari pre-test, post-test dan follow up dari skor keterikatan karyawan kelompok eksperimen dan kelompok kontrol ditampilkan dalam Tabel 1 sebagai berikut:

Tabel 1. Perbandingan Skor Pre-test, Post-test dan Follow up Kelompok Eksperimen dan Kelompok Kontrol

\begin{tabular}{ccccccc}
\hline \multirow{2}{*}{ Kode } & \multicolumn{3}{c}{ Pre-test } & \multicolumn{2}{c}{ Post-test } & \multicolumn{2}{c}{ Follow up } \\
\cline { 2 - 7 } Subjek & Skor & Kategori & Skor & Kategori & Skor & Kategori \\
\hline KE1 & 93 & Sedang & 124 & Tinggi & 137 & Tinggi \\
\hline KE2 & 91 & Sedang & 125 & Tinggi & 138 & Tinggi \\
\hline KE3 & 94 & Sedang & 126 & Tinggi & 144 & Tinggi \\
\hline KK1 & 82 & Sedang & 91 & Sedang & 89 & Sedang \\
\hline KK2 & 96 & Sedang & 96 & Sedang & 92 & Sedang \\
\hline KK3 & 82 & Sedang & 94 & Sedang & 93 & Sedang \\
\hline KK4 & 96 & Sedang & 96 & Sedang & 93 & Sedang \\
\hline KK5 & 94 & Sedang & 93 & Sedang & 94 & Sedang \\
\hline KK6 & 94 & Sedang & 94 & Sedang & 93 & Sedang \\
\hline KK7 & 95 & Sedang & 93 & Sedang & 94 & Sedang \\
\hline KK8 & 94 & Sedang & 94 & Sedang & 93 & Sedang \\
\hline KK9 & 96 & Sedang & 92 & Sedang & 93 & Sedang \\
\hline KK10 & 96 & Sedang & 94 & Sedang & 93 & Sedang \\
\hline KK11 & 90 & Sedang & 85 & Sedang & 86 & Sedang \\
\hline KK12 & 96 & Sedang & 93 & Sedang & 95 & Sedang \\
\hline KK13 & 96 & Sedang & 93 & Sedang & 94 & Sedang \\
\hline KK14 & 93 & Sedang & 92 & Sedang & 91 & Sedang \\
\hline KK15 & 82 & Sedang & 82 & Sedang & 79 & Sedang \\
\hline KK16 & 94 & Sedang & 93 & Sedang & 90 & Sedang \\
\hline Keterangan: KE & kelompok eksperimen; KK $=$ kelompok kontrol.
\end{tabular}

Berdasarkan Tabel 1 di atas, dapat dilihat bahwa pada saat pre-test seluruh subjek memiliki tingkat keterikatan karyawan pada kategori sedang. Setelah diberikan pelatihan kebermaknaan kerja sebanyak empat kali pertemuan, seluruh subjek pada kelompok eksperimen mengalami peningkatan skor keterikatan karyawan dari kategori sedang menjadi kategori tinggi. Sementara itu, subjek pada kelompok kontrol tidak mengalami peningkatan yaitu tetap pada kategori sedang. Selanjutnya, hasil follow-up kelompok eksperimen tetap berada pada kategori tinggi dengan skor yang meningkat, sedangkan kelompok kontrol tetap pada kategori sedang dengan skor yang cenderung tetap dan turun. Oleh karena itu, dapat disimpulkan bahwa skor post-test kelompok eksperimen mengalami peningkatan yang signifikan dari hasil pre-test, begitupun juga pada skor follow up yang mengalami peningkatan dibandingkan dengan pre-test. 
Selanjutnya, skor skala keterikatan karyawan tersebut diuji homogenitasnya menggunakan teknik homogeneity of variances. Tabel output test of homogenity of variances menunjukkan nilai $p=0.088$. Hasil ini berarti bahwa sebaran data pre-test pada kelompok eksperimen dan kelompok kontrol bersifat homogen. Data post-test menghasilkan nilai $p=$ 0.507 , yang menunjukkan bahwa sebaran data post-test pada kelompok eksperimen dan kelompok kontrol bersifat homogen. Selanjutnya, pada data follow up nilai $p=0.258$ yang berarti bahwa sebaran data follow up pada kelompok eksperimen dan kelompok kontrol bersifat homogen.

Setelah mengetahui bahwa kedua kelompok bersifat homogen, tahap selanjutnya ialah melakukan uji hipotesis terhadap hasil skor keterikatan karyawan yang diperoleh subjek penelitian. Uji hipotesis pertama dilakukan menggunakan Friedman test terhadap skor pre-test, post-test dan follow up. Uji Friedman digunakan untuk menguji hipotesis komparatif $k$ sampel yang berpasangan (related) bila datanya berbentuk ordinal (ranking) (Rihandoyo 2009). Tabel 2 berikut ini menampilkan hasil analisis friedman test:

Tabel 2. Hasil Analisis Friedman Test terhadap Pre-test, Post-Test dan Follow Up

\begin{tabular}{|c|c|c|c|c|c|}
\hline \multirow[b]{2}{*}{ Kelompok } & \multicolumn{3}{|c|}{ Mean } & \multirow{2}{*}{$\begin{array}{c}\text { Asymp. } \\
\text { Sig. }\end{array}$} & \multirow[b]{2}{*}{ Deskripsi } \\
\hline & $\begin{array}{l}\text { Pre- } \\
\text { test }\end{array}$ & $\begin{array}{c}\text { Post- } \\
\text { test }\end{array}$ & $\begin{array}{c}\text { Follow } \\
\text { up }\end{array}$ & & \\
\hline Eksperimen & 93.33 & 125.00 & 139.67 & 0.050 & $\begin{array}{c}\text { Ada } \\
\text { perbedaan } \\
\text { yang } \\
\text { signifikan }\end{array}$ \\
\hline Kontrol & 92.56 & 93.00 & 92.81 & 0.528 & $\begin{array}{c}\text { Tidak ada } \\
\text { perbedaan } \\
\text { yang } \\
\text { signifikan }\end{array}$ \\
\hline
\end{tabular}

Berdasarkan Tabel 2, kelompok eksperimen memperoleh nilai $p$ sebesar 0.050, sehingga dapat disimpulkan bahwa terdapat perbedaan yang secara marginal signifikan terkait selisih skor mean pretest, posttest dan follow up pada kelompok eksperimen.
Sementara itu, kelompok kontrol menunjukkan nilai $p$ sebesar 0.528 , yang menunjukkan bahwa tidak ada perbedaan yang signifikan terkait selisih skor mean pretest, posttest dan follow up pada kelompok kontrol.

Berdasarkan hasil tersebut, maka hipotesis yang diajukan pada penelitian ini diterima. Sebagai kesimpulannya, terdapat efektivitas pemberian perlakuan berupa pelatihan kebermaknaan kerja dalam meningkatkan keterikatan karyawan subjek pada kelompok eksperimen. Perawat di Rumah Sakit X Padang mengalami peningkatan keterikatan karyawan setelah mengikuti pelatihan kebermaknaan kerja dibandingkan dengan perawat yang tidak mengikuti pelatihan kebermaknaan kerja.

Selanjutnya, peneliti melakukan uji analisis menggunakan Mann-Whitney $U$ test. Uji Mann-Whitney merupakan uji beda yang dilakukan untuk mengetahui perbedaan ratarata data dua sampel yang tidak berpasangan (Rihandoyo 2009). Berikut merupakan tabel hasil uji Mann-Whitney:

Tabel 3. Hasil Analisis Mann-Whitney U Test

\begin{tabular}{lccc}
\hline & \multicolumn{3}{c}{ Gain score } \\
\cline { 2 - 4 } & $\begin{array}{c}\text { Pre- } \\
\text { post }\end{array}$ & $\begin{array}{c}\text { Pre- } \\
\text { follow }\end{array}$ & $\begin{array}{c}\text { Post- } \\
\text { follow }\end{array}$ \\
\hline Mann-Whitney $U$ & 0.000 & 0.000 & 0.000 \\
\hline$Z$ & -2.690 & -2.686 & -2.689 \\
\hline Asymp. Sig. (2-tailed) & 0.007 & 0.007 & 0.007 \\
\hline $\begin{array}{l}\text { Exact. Sig. [2*(1- } \\
\text { tailed Sig.)] }\end{array}$ & 0.002 & 0.002 & 0.002 \\
\hline $\begin{array}{l}\text { Keterangan: Pre }=\text { pre-test, Post } \\
\text { follow up. post-test, Follow }=\end{array}$ & & & \\
\multicolumn{1}{c}{ Berdasarkan } & output & dalam uji & Mann-
\end{tabular}
Whitney di atas diketahui bahwa nilai Exact. Sig. [2*(1-tailed Sig.)] sebesar $p=0.002$. Oleh karena itu, dapat disimpulkan bahwa hipotesis yang diajukan oleh peneliti dapat diterima. Hal ini berarti terdapat perbedaan yang signifikan antara skor keterikatan karyawan pada kelompok eksperimen dan kelompok kontrol.

Mengacu pada kedua hasil uji analisis di atas, dapat disimpulkan bahwa pelatihan kebermaknaan kerja yang diberikan kepada 
kelompok eksperimen mampu meningkatkan keterikatan karyawan pada perawat di Rumah Sakit X Padang secara signifikan. Sementara subjek pada kelompok kontrol yang tidak mengikuti pelatihan kebermaknaan kerja tidak mengalami peningkatan skor keterikatan karyawan.

\section{Diskusi}

Penelitian ini bertujuan untuk melihat efektivitas pelatihan kebermaknaan kerja dalam meningkatkan keterikatan karyawan pada perawat di Rumah Sakit X Padang. Pengujian hipotesis dilakukan untuk mengetahui perbedaan tingkat keterikatan karyawan pada perawat yang diberikan pelatihan kebermaknaan kerja (kelompok eksperimen) dibandingkan dengan perawat yang tidak diberikan pelatihan (kelompok kontrol). Hasil dalam penelitian ini menunjukkan adanya perbedaan yang signifikan keterikatan karyawan pada saat sebelum dan setelah perlakuan diberikan.

Efektivitas pelatihan kebermaknaan kerja tidak hanya dapat dibuktikan melalui hasil uji analisis, namun juga dapat diketahui melalui hasil evaluasi pelatihan yang dilakukan terhadap peserta pelatihan. Berdasarkan hasil evaluasi terhadap worksheet yang dikerjakan oleh peserta selama pelatihan berlangsung, secara umum motivasi terbesar peserta dalam bekerja dipengaruhi oleh pasien yang sedang dirawat di rumah sakit. Peserta memiliki rasa tanggung jawab yang besar terhadap pasien dalam pekerjaannya sebagai seorang perawat.

Peserta juga mengungkapkan bahwa kehadiran perawat di rumah sakit merupakan hal yang sangat diharapkan oleh pasien. Selain itu, peserta juga mengungkapkan bahwa alasannya untuk berangkat kerja ialah untuk mengetahui tingkah laku atau kejadian unik yang akan terjadi pada saat bekerja dalam menangani pasien. Hal tersebut menunjukkan bahwa peserta merasa bertanggung jawab terhadap pekerjaan, bangga atas pekerjaan yang dilakukannya, merasa tertantang dengan hal-hal baru dalam pekerjaannya serta merasa bermanfaat bagi orang lain dalam hal ini pasien.

Ciri-ciri perilaku karyawan yang muncul pada peserta pelatihan kebermaknaan kerja tersebut termasuk dalam aspek dedication pada keterikatan karyawan. Selanjutnya, pada saat melakukan evaluasi pelatihan terdapat beberapa peserta yang mengungkapkan bahwa waktu terasa lebih cepat berlalu pada saat bekerja. Terdapat salah seorang peserta yang menyampaikan bahwa sebelum mengikuti pelatihan subjek merasakan waktu berjalan sangat lama ketika sedang menjalani dinas malam hari. Setelah mengikuti pelatihan, subjek menikmati pekerjaan yang dilakukan sehingga waktu terasa lebih cepat berlalu meskipun pada saat dinas malam hari. Kondisi tersebut menunjukkan ciri keterikatan karyawan pada aspek absorption yaitu merasa senang berkutat dengan pekerjaan sehingga waktu berlalu dengan cepat.

Berdasarkan uraian di atas, dapat disimpulkan bahwa pelatihan kebermaknaan kerja efektif untuk meningkatkan keterikatan karyawan. Meskipun demikian, pelatihan kebermaknaan kerja yang diberikan dirasa masih memiliki kekurangan diantaranya ialah subjek penelitian yang hanya terdiri dari perawat di Rumah Sakit X Padang. Keterbatasan lain dalam penelitian ini terkait dengan waktu pelaksanaan pelatihan yang kurang disesuaikan dengan jadwal kerja peserta. Hal ini mempengaruhi tingkat kehadiran subjek yang semakin berkurang dibandingkan pada pertemuan pertama. Jumlah kehadiran subjek kelompok eksperimen pada pertemuan pertama sebanyak 16 orang, namun hanya terdapat tiga orang yang mengikuti pelatihan hingga pertemuan terakhir.

Mengacu pada kondisi pelatihan di atas, maka diharapkan kepada subjek penelitian agar dapat terus mempertahankan keterikatan karyawan dan mampu memaknai pekerjaan sebagaimana yang telah diperoleh dari pelatihan kebermaknaan kerja. Selanjutnya, kepada rumah sakit selaku organisasi yang menaungi 
subjek dalam penelitian ini diharapkan dapat memberikan pelatihan kebermaknaan kerja terhadap seluruh karyawan selain perawat untuk meningkatkan keterikatan karyawan. Beberapa aktivitas atau mini project yang disimulasikan dalam pelatihan diharapkan juga dapat diterapkan kepada karyawan Rumah Sakit X Padang.

Selanjutnya, berkaca pada keterbatasan dan kelemahan dalam penelitian ini maka peneliti berharap agar peneliti selanjutnya dapat melakukan uji efektivitas pelatihan kebermaknaan kerja untuk meningkatkan keterikatan karyawan pada subjek dengan karakteristik yang berbeda. Hal ini diharapkan agar dapat melihat efektivitas pelatihan kebermaknaan kerja pada beragam kasus psikologi industri dan organisasi lainnya. Peneliti selanjutnya diharapkan dapat mempertahankan mortalitas subjek dalam mengikuti proses pelatihan dari awal sampai akhir. Oleh karena itu, peneliti selanjutnya dapat menyiapkan waktu pelaksanaan pelatihan yang memungkinkan subjek untuk mengikuti pelatihan secara penuh.

\section{Daftar Pustaka}

Arikunto, S. (2013). Prosedur penelitian suatu pendekatan praktik. Jakarta: PT Rineka Cipta.

Bakker, A., \& Demerouti, E. (2007). The job demands-resources: State of the art. Journal of Managerial Psychology, 22(3), 309-328. https://doi.org/10.1108/0268394071073 3115

Bakker, A., \& Demerouti, E. (2008). Towards a model of work engagement. Career Development International, 13(3), 209223.

https://doi.org/10.1108/1362043081087 0476

Bakker, A., \& Leiter, M. (2010). Work engagement: $A$ handbook of essential theory and research. New York: Psychology Press.
Fairlie, P. (2011). Meaningful work, employee engagement, and other key employee outcomes: Implications for human resource development. Advances in Developing Human Resources, 13, 508. https://doi.org/10.1177\%2F1523422311 431679

Firdaus, M. (2017). Pengaruh nilai kerja, makna kerja, kepuasan kerja terhadap work engagement pada organisasi sosial non profit YDSF di Surabaya (Disertasi, UIN Sunan Ampel Surabaya, Surabaya, Indonesia). Diakses dari http://digilib.uinsby.ac.id/19141/

Gallup. (2017). Employee engagement survey report. Diakses dari https://www.slideshare.net/adrianbouce $\mathrm{k} / \mathrm{state}$-of-the-global-workplace-gallupreport-2017

Hidayat, M. Z. (2018). Pelatihan kebermaknaan kerja untuk meningkatkan keterikatan pegawai (employee engagement) pada PNS di Pemerintah Kota Surakarta (Tesis, Universitas Muhammadiyah Surakarta, Surakarta, Indonesia). Diakses dari http://eprints.ums.ac.id/62432/

Kahn, W. A. (1990). Psychological conditions of personal engagement and disengagement at work. Academy of Management Journal, 33(4), 692-724. https://doi.org/10.5465/256287

Kebijakan kesehatan Indonesia. (2010). Diakses dari Menteri Kesehatan Republik Indonesia:

http://kebijakankesehatanindonesia.net/s ites/default/files/file/2011/kepmenkes/K MK\%20No.\%20340\%20ttg\%20Klasifik asi\%20Rumah\%20Sakit.pdf

May, D., Gilson, R., \& Harter, L. (2004). The psychological conditions of meaningfulness, safety and availability and the engagement of the human spirit at work. Journal of Occupational and Organizational Psychology, 11-37. 
https://doi.org/10.1348/0963179043229 15892
21-23.

https://doi.org/10.1006/jrpe.1997.2162

Nusantria, S. (2012). Employee engagement: Anteseden dan konsekuensi (Skripsi, Fakultas Ekonomi dan Bisnis Universitas Diponegoro, Semarang, Indonesia). Diakses dari http://eprints.undip.ac.id/32106/1/Skrips i_3.pdf

Rae, L. (2005). Using Training aids: Memaksimalkan potensi alat bantu dalam pendidikan dan latihan. Jakarta: PT. Gramedia.

Rihandoyo. (2009). Alat uji hipotesis penelitian non parametrik. Semarang: FISIP UNDIP.

Sarwono, S., \& Meinarno, E. (2011). Psikologi sosial. Jakarta: Salemba Humanika.

Schaufeli, W. B. (2013). What is engagement? Employee in theory and practice. London: Routledge.

Schaufeli, W., \& Bakker, A. (2004). Job demands, job resources, and their relationship with burnout and engagement: A multi-sample study. Journal of Organization Behavior, 25, 293-315. https://doi.org/10.1002/job.248

Steger, M., \& Dik, B. (2009). If one is searching for meaning in life, does meaning in work help? Applied Psychology: Health and Well-Being, 1, 303-320. https://doi.org/10.1111/j.17580854.2009.01018.x

Sugiyono. (2014). Metode Penelitian kuantitatif, kualitatif dan $R \quad \& \quad D$. Bandung: Penerbit Alfabeta.

Titien. (2016). Penyusunan dan pengembangan alat ukur employee engagement. Psikohumaniora: Jurnal Penelitian Psikologi, $\quad 1(1), \quad 113-130$. http://dx.doi.org/10.21580/pjpp.v1i1.95 8

Wrzesniewski, A., McCauley, C., Rozin, P., \& Schwartz, B. (1997). Jobs, career, and calling: People's relations to their work. Journal of Research in Personality, 31, 